\title{
Cholesteryl Ester Transfer Protein
}

National Cancer Institute

\section{Source}

National Cancer Institute. Cholesteryl Ester Transfer Protein. NCI Thesaurus. Code C40097.

Cholesteryl ester transfer protein (493 aa, $\sim 55 \mathrm{kDa}$ ) is encoded by the human CETP gene.

This protein is involved in cholesterol transport, metabolism, and homeostasis. 